\title{
Makna simbolik Tradisi Dawuhan Dusun Ngiliran Desa Ngiliran Kecamatan Panekan Kabupaten Magetan
}

\author{
Aprillia Setianingsih, Deny Wahyu Apriadi* \\ Universitas Negeri Malang, Jl. Semarang No. 5 Malang, Jawa Timur, Indonesia \\ *Penulis korespondensi, Surel: deny.apriyadi.fis@um.ac.id
}

Paper received: 01-04-2021; revised: 15-04-2021; accepted: 30-04-2021

\begin{abstract}
Abstrak
Suatu tindakan manusia yang dilakukan secara turun temurun yang berasal dari setiap aspek kehidupan manusia serta merupakan suatu usaha untuk meringankan kehidupan manusia bisa dikatakan sebagai "tradisi ". Hal ini berarti bahwa tradisi juga merupakan bagian dari kebudayaan. Tradisi Dawuhan adalah salah satu tradisi bersih desa yang wajib dilaksanakan setahun sekali di bulan Desember sebagai perwujudan rasa syukur masyarakat kepada Tuhan Yang Maha Esa. Teori dalam penelitian ini yaitu Teori Interaksionisme Simbolik. Dalam penelitian ini menggunakan pendekatan kualitatif dengan jenis penelitian deskriptif. Adapun hasil dari penelitian adalah Mind (pemikiran) pemikiran yang bertujuan sebagai sarana komunikasi yang dilakukan kepada Sang Maha Kuasa. Self (diri) masyarakat dapat mengaplikasikan makna simbolik yang terdapat dalam Tradisi Dawuhan dan masyarakat dapat mempercayai terkait makna simbolik yang terdapat dalam tradisi tersebut. Society (masyarakat) masyarakat bersama-sama membentuk suatu konstruksi untuk membangun suatu makna simbolik dalam ritual.
\end{abstract}

Kata kunci: tradisi; makna simbolik

\section{Pendahuluan}

Magetan adalah salah satu kabupaten di Provinsi Jawa Timur, Indonesia. Luas Kabupaten Magetan adalah 688,85 km2 dengan jumlah penduduk 821.000 jiwa pada tahun 2015. Batas wilayah utara Kabupaten Magetan adalah Kabupaten Ngawi, timur berbatasan dengan Kabupaten Madiun, selatan adalah Kabupaten Ponorogo dan barat berbatasan langsung dengan Kabupaten Karanganyar. Secara administrasi Kabupaten Magetan terdiri dari 18 kecamatan dengan 235 desa. Oleh karena itu, terdapat banyak tradisi dan kebiasaan di Kabupaten Magetan terutama di Dusun Ngiliran Kecamatan Panekan yang diwujudkan dalam bentuk ritual-ritual atau tradisi. Bagi masyarakat Dusun Ngiliran, tradisi merupakan implementasi dari nilai-nilai keagamaan yang merupakan sebuah sarana mendekatkan diri kepada Tuhan Yang Maha Esa. Sehingga tidak jarang apabila ritual-ritual yang mereka lakukan menjadi bagian dari kebiasaan dan kehidupan mereka.

Bersih desa merupakan wujud dari sebuah kebudayaan yang masih dilaksanakan oleh masyarakat Jawa, khususnya Dusun Ngiliran Kabupaten Magetan atau lebih dikenal dengan istilah Dawuhan. Dalam kepercayaan masyarakat Kabupaten Magetan terutama Dusun Ngiliran, Dawuhan tergolong tradisi karena telah dilakukan turun temurun sejak zaman nenek moyang dahulu hingga sekarang. Dalam tradisi ini menggunakan banyak perlengkapan yang dianggap memiliki makna simbol tertentu dalam perspektif dan pandangan masyarakat Ngiliran sejak jaman dahulu. Tradisi ini rutin dilakukan setiap tahun sebagai tradisi bersih desa dan sebagai tolak balak.

Dalam penelitian ini mencoba menggali informasi dari penelitian sebelumnya untuk perbandingan. Selain itu, peneliti juga menggali informasi melalui buku dan jurnal untuk 
memperoleh informasi yang sudah ada sebelumnya mengenai teori maupun konsep yang berkaitan dengan penelitian peneliti.

Dalam penelitian oleh Khamidah (2019) berfokus pada nilai-nilai pendidikan agama islam dalam tradisi bersih desa di Desa Purbosari Kecamatan Seluma Barat Kabupaten Seluma yang berlatar belakang dari adanya perbedaan persepsi antara masyarakat Bengkulu dengan masyarakat Suku Jawa di Bengkulu. Nilai-nilai agama tersebut antara lain aqidah yaitu berupa keyakinan warga terhadap Allah SWT, nilai ibadah berupa munajat, doa bersama, dzikir, dan sholawat. Nilai akhlak berupa ajaran bersedekah dan bertanggung jawab, serta nilai kemasyarakatan berupa gotong royong dan melestarikan tradisi.

Dalam penelitian Ningrum, S. N. (2018) berfokus pada nilai persatuan dalam pancasila pada tradisi bersih desa (Punden) di Desa Tambakboyo Kecamatan Tawangsari Kabupaten Sukoharjo. Nilai persatuan pancasila meliputi implementasi nilai persatuan yaitu berupa tindakan saling menolong dan bekerja sama serta mampu mengembangkan persatuan dan kesatuan berdasarkan bhineka tunggal ika. Kendala yang dihadapi perbedaan perspektif antar masyarakat mengenai tradisi tersebut. Dan solusi yang diberikan berupa mengadakan rapat dan sosialisasi agar menerima tanggung jawab dengan baik.

Dalam penelitian Rizkiawan, I (2017) berfokus mengenai pandangan masyarakat tentang makna sesajen dimana sebagian masyarakat memberikan respon positif sebab menganggap bahwa sesajen pada upacara bersih desa dianggap merupakan salah satu unsur penting yang memiliki makna tertentu. Tidak hanya itu, dalam penelitian ini juga mengungkapkan bahwa kebudayaan menjadi faktor yang paling mempengaruhi mengenai makna sesajen karena telah terbentuk dari tahun ke tahun.

Perbedaan penelitian dengan penelitian terdahulu adalah memfokuskan pada makna serta prosesi tradisi "Dawuhan" menurut masyarakat Dusun Ngiliran yang menggunakan berbagai keperluan yang tentunya memiliki simbol makna tersendiri.

Oleh karena itu, penelitian ini penting dilakukan untuk mengetahui makna simbolik yang terkandung dalam tradisi "Dawuhan" serta mengeksplorasi kebudayaan di Dusun Ngiliran Desa Ngiliran Kecamatan Panekan Kabupaten Magetan dikarenakan kurangnya pemahaman masyarakat mengenai makna simbolik yang terkandung dalam prosesi dan perlengkapan yang digunakan dalam tradisi tersebut.

Penelitian ini bertujuan untuk mengidentifikasi tradisi "Dawuhan" yang dilaksanakan oleh masyarakat Dusun Ngiliran dan untuk mengidentifikasi makna simbolik dalam tradisi "Dawuhan" oleh masyarakat Dusun Ngiliran sebagai wujud implementasi dari nilai-nilai keagamaan yang merupakan sebuah sarana dengan dengan tujuan mendekatkan diri kepada Tuhan Yang Maha Esa.

Dengan dilaksanakannya penelitian ini diharapkan memiliki manfaat bagi banyak pihak antara lain: Bagi peneliti, diharapkan bermanfaat untuk menambah pengetahuan dan mengetahui makna simbolik prosesi tradisi "Dawuhan" di Dusun Ngiliran Desa Ngiliran Kecamatan Panekan Kabupaten Magetan. Bagi masyarakat penelitian ini diharapkan memberikan informasi terkait tradisi "Dawuhan" dan memberikan pandangan kepada masyarakat bahwa di Kabupaten Magetan tepatnya Dusun Ngiliran terdapat suatu tradisi yang 
menjadi suatu kebudayaan. Selain itu, untuk menambah wawasan terkait makna simbolik yang terkandung dalam tradisi "Dawuhan” di Dusun Ngiliran.

\subsection{Tradisi dalam Masyarakat}

Aktivitas manusia secara turun temurun yang bersumber dari setiap aspek kehidupan manusia dan merupakan cobaan untuk meringankan kehidupan manusia dikatakan sebagai "tradisi". Ini berarti tradisi juga merupakan elemen dari kebudayaan. Tradisi berasal dari kata tradition yang berarti segala sesuatu yang diturunkan dari generasi ke generasi (Lamazi, 2005). Tradisi, dalam arti luas, merupakan warisan dan praktik budaya generasi sebelumnya yang masih dipertahankan hingga saat ini. Ritual ritual adalah praktik yang telah diturunkan atau diturunkan dari generasi dahulu ke generasi saat ini (Sedyawati, 1991). Menurut koentjaraningrat (2015), setidaknya ada tiga wujud kebudayaan antara lain: (1) Wujud budaya sebagai tempat berkumpulnya gagasan, nilai, norma, dan aturan yang merupakan jenis budaya terbaik. Yang bisa dikatakan sempurna merupakan wujud dari kebudayaan. Lokasinya ada di dalam kepala atau dengan kata lain di dalam benak warga masyarakat tempat budaya tersebut hidup. (2) Wujud kebudayaan sebagai suatu kompleks aktivitas serta tindakan berpola dari manusia dalam masyarakat. Wujud yang kedua ini dapat disebut dengan sistem sosial. Dalam hal ini berarti suatu pola atau tindakan berasal dari orang tersebut. Struktur sosial ini terdiri dari aktivitas manusia yang berkomunikasi, berhubungan, dan mengidentifikasi satu sama lain secara teratur, seringkali mengikuti pola tertentu berdasarkan adat istiadat dan perilaku. (3) Wujud kebudayaan sebagai benda-benda hasil karya manusia yang disebut dengan wujud Fisik. Wujud fisik ini berupa seluruh hasil fisik dan aktivitas, perbuatan, dan karya semua manusia dalam masyarakat. Sifatnya paling konkret dan berupa benda-benda yang dapat dilihat, diraba dan difoto.

\subsection{Tradisi Dawuhan}

Sebagian orang Jawa, khususnya Jawa Timur masih melaksanakan tradisi yang dinamakan bersih desa. Terutama Dusun Ngiliran Kecamatan Panekan Kabupaten Magetan, menamakan tradisi tersebut dengan "Dawuhan". Tradisi Dawuhan ini dilaksanakan satu kali dalam setahun. Bertempat di sebuah sendang yang dinamakan Sendang Molang dan dilaksanakan secara periodik oleh pemerintah Desa Ngiliran serta masyarakat setempat. Dalam kegiatan tersebut dihadiri oleh Jajaran Forkopimca, Pemerintah Desa setempat serta lembaga dan seluruh warga masyarakat Desa Ngiliran. Tradisi dawuhan ini diawali dengan kegiatan kerja bakti membersihkan area sekitar mata air, dilanjutkan prosesi dan diakhiri dengan membagikan makanan. Tidak selesai disitu, pada malam harinya masih dilanjutkan dengan pagelaran wayang kulit mulai pukul 8 malam hingga pagi hari.

\subsection{Teori Interaksi Simbolik}

Menurut Effendy (1989), interaksi simbolik merupakan pemahaman yang menyatakan bahwa hakikat interaksi sosial antar individu, begitu pula antara individu dan kelompok, kelompok dan kelompok terjadi karena komunikasi.

Interaksi Simbolik ada karena ide dasar pembentukan makna berasal dari pikiran manusia (Mind) tentang diri (Self) dan hubungannya di pusat interaksi sosial, pengalaman simbolik terjadi dan tujuan akhirnya adalah untuk memediasi dan menafsirkan makna dalam kelompok (Society) di mana orang tersebut berada. Menurut Douglas (1970) dalam Ardianto 
(2007), makna itu berasal dari interaksi, dan tidak ada cara lain untuk membentuk makna, selain dengan membangun hubungan dengan individu lain melalui interaksi.

Pada interaksi simbolik terdapat tiga ide dasar yang digunakan dalam teori ini yang terdiri dari: (1) Pikiran (Mind) didefinisikan sebagai suatu kemampuan dalam menggunakan simbol yang memiliki makna sosial yang sama, dimana setiap individu harus mengembangkan pikiran mereka melalui interaksi dengan individu lain. (2) Diri (Self) didefinisikan sebagai kemampuan untuk merefleksikan diri oleh setiap individu dari penilaian perspektif orang lain, di dalam teori interaksionis simbolik mengemukakan tentang konsep diri (self) beserta lingkungan luarnya. (3) Masyarakat (Society) dicirikan sebagai jaringan hubungan sosial yang dibangun oleh setiap orang dalam masyarakat, dan setiap individu secara aktif dan rela terlibat dalam tindakan yang mereka inginkan, yang mengarahkan manusia dalam mengambil peran.

Suatu pondasi yang terbentuk dari kehidupan masyarakat memunculkan sebuah pemahaman bahwa kunci untuk memahami segala kehidupan manusia menurut teori interaksi simbolik yakni menunjuk pada "komunikasi" atau "simbol-simbol". Sifat atau ciri khas dari interaksi antar manusia ditunjuk oleh interaksi simbolik. Sehingga, dapat diartikan manusia dapat saling mendefinisikan ataupun menerjemahkan segala tindakan yang dilakukan, baik dalam berinteraksi dengan individu atau kelompok lain maupun berinteraksi dengan diri individu itu sendiri. Pemakaian simbol-simbol bahasa, segala ketentuan yang ada pada adat istiadat, kepercayaan atau agama dan pandangan-pandangan lain tentu dilibatkan dalam proses pembentukan atau berlangsungnya interaksi.

\section{Metode}

Penelitian ini menggunakan pendekatan kualitatif untuk mendapatkan hasil yang terperinci dan diharapkan dapat mengidentifikasi secara lebih mendalam tentang fenomena yang diteliti. Menurut Kirk \& Miller (1986), penelitian kualitatif adalah tradisi khusus ilmu sosial yang didasarkan pada pengamatan manusia baik dalam lingkup maupun terminologinya. Hal tersebut mengakui aspek makna yang baik dalam berbagai konteks di bidang keberagaman manusia.

Penelitian ini tergolong jenis penelitian deskriptif. Jenis atau penelitian deskriptif menurut Neuman (2000) merupakan penelitian yang bertujuan untuk menyajikan gambaran yang spesifik terkait situasi, setting sosial, dan hubungan. Pada penelitian ini peneliti menggunakan metode kualitatif dengan pendekatan deskriptif karena peneliti ingin mengidentifikasi dan mendeskripsikan fenomena mengenai tradisi "Dawuhan" di Dusun Ngiliran Kecamatan Panekan secara lebih mendalam.

Dalam penelitian ini, peneliti sebagai pengamat fenomena yang terjadi secara langsung datang ke lapangan dan melakukan wawancara pada narasumber yang telah ditentukan. Pada 15 Oktober 2020 peneliti melakukan pra penelitian dengan agenda konfirmasi terhadap pemerintah desa Dusun Ngiliran terkait akan diadakannya penelitian mengenai tradisi "Dawuhan". Pra penelitian ini bertujuan untuk memperoleh data informan sebagai agenda wawancara penelitian kepada tokoh adat, kepala desa dan tokoh masyarakat Desa Ngiliran Kecamatan Panekan.

Lokasi penelitian dilakukan di Dusun Ngiliran Desa Ngiliran Kecamatan Panekan Kabupaten Magetan, Jawa Timur. Peneliti memilih lokasi penelitian tersebut karena di Dusun Ngiliran Desa Ngiliran Kecamatan Panekanyang sekitar setahun lalu melaksanakan Tradisi 
Bersih Desa Dawuhan dan akan kembali dilakukan tanggal 15 Desember 2020. Sehingga dapat diartikan bahwa daerah tersebut masih terus melakukan dan melestarikan Tradisi Dawuhan.

Sumber data yang digunakan dalam penelitian ini adalah sumber data primer dan sumber data sekunder. Sumber data primer dalam penelitian ini diperoleh melalui hasil wawancara dengan para informan yang diantaranya adalah tetua adat, tokoh masyarakat dan khususnya generasi muda Dusun Ngiliran. Sumber data sekunder didapat dari berbagai sumber bacaan atau atau tulisan - tulisan yang memuat informasi yang berhubungan dengan tradisi Dawuhan. Dokumentasi Dalam penelitian ini dokumentasi merupakan sumber data yang berbentuk foto - foto dari hasil penelitian lapangan dan wawancara langsung kepada informan.

Teknik pengumpulan data, wawancara dengan penentuan informan menggunakan purposive sampling. Alasan pemilihan teknik purposive sampling adalah pemilihan informan didasarkan atas kemampuannya dalam memberikan data yang akurat dan ditentukan secara purposive. Observasi dapat didefinisikan sebagai suatu kegiatan yaitu mengamati dan merekam suatu gejala dengan tujuan kegiatan ilmiah.

Dalam penelitian ini teknik analisis data yang digunakan adalah teknik analisis data secara deskriptif dengan analisis model interaktif dari Miles dan Huberman (Miles \& Huberman, 1992), yaitu pengumpulan data, reduksi data, penyajian data, penarikan kesimpulan (verifikasi).

\section{Hasil dan Pembahasan}

\subsection{Hasil penelitian}

Dalam bab ini, akan dipaparkan terkait hasil penelitian di lapangan dan temuan penelitian yang disajikan dalam beberapa sub bab, yaitu: (1) Gambaran umum lokasi (2) makna dan tujuan tradisi (3) prosesi dan ketentuan khusus tradisi (4) upaya pelestarian (5) temuan penelitian.

Magetan adalah sebuah kabupaten di Provinsi Jawa Timur, Indonesia. Luas Kabupaten Magetan adalah $688,85 \mathrm{~km}^{2}$ dengan jumlah penduduk 821.000 jiwa pada tahun 2015. Batas wilayah utara Kabupaten Magetan adalah Kabupaten Ngawi, timur berbatasan dengan Kabupaten Madiun, selatan adalah Kabupaten Ponorogo dan barat berbatasan langsung dengan Kabupaten Karanganyar. Secara administrasi Kabupaten Magetan terdiri dari 18 kecamatan dengan 235 desa. Salah satunya adalah Desa Ngiliran yang dipilih menjadi lokasi penelitian.

Dalam penelitian ini terdapat informan yang terdiri dari 4 orang. Dengan jumlh informan kunci sebnyak 1 orang dan informan pendukung sebanyak 3 orang. Informan penelitian merupakan warga masyarakat Dusun Ngiliran Desa Ngiliran Kecamatan Panekan Kabupaten Magetan. Berikut adalah profil dari masing-masing informan tersebut. 


\subsubsection{Makna Tradisi Dawuhan}

Pemaknaan terhadap Tradisi Dawuhan seringkali dihubungkan dengan prosesi dan perlengkapan dalam Tradisi Dawuhan. Informan yang memiliki makna akan hal ini adalah Purnomo (37) yang memaknai Tradisi Dawuhan terdapat urutan prosesi dan yang paling utama adalah prosesi bakar menyan. Menurut Tabri (52) makna simbolik Tradisi Dawuhan adalah bunga tabur dan sesajen. Dalam tradisi ini, kepercayaan masyarakat nenek moyang pembangun Sumber Molang menyukai wangi-wangian dari bunga tabur dan dari pembakaran sesajen. Informan yang memiliki makna akan hal ini adalah Sulangkir (43). Makna prosesi dan perlengkapan yang digunakan dalam Tradisi Dawuhan digunakan sebagai wujud rasa syukur. Menurut Endro (30), beliau menyatakan bahwa

“...Makna simbolik yang terkandung dari tradisi ini yaitu mengingatkan bahwa masyarakat agar selalu bersyukur atas apa yang diberikan oleh Tuhan Yang Maha Esa terutama air sumber yang bisa menjadikan kelancaran kehidupan dan suksesnya pertanian."

(Sumber: Endro, 14 Desember 2020)

Sama halnya dengan Sulangkir (43), beliau menyatakan bahwa Tradisi Dawuhan yakni sebagai doa permohonan dan wujud syukur kepada Tuhan Yang Maha Esa atas melimpahnya sumber mata air yang tidak pernah kering sampai saat ini.

\subsubsection{Tujuan Tradisi Dawuhan}

Tradisi Dawuhan telah menjadi wujud kebudayaan yang diwariskan dan menjadi kebudayaan bagi masyarakat Dusun Ngiliran Desa ngiliran Kecamatan Panekan Kabupaten Magetan. Tradisi ini tidak mungkin muncul begitu saja di tengah-tengah masyarakat, melainkan tradisi ini tentunya telah dibawa oleh nenek moyang dan dilaksanakan secara terus-menerus dan turun-temurun dari generasi ke generasi. Adapun alasan mengapa tradisi ini masih hidup dan terus dilaksanakan oleh Masyarakat Desa Ngiliran karena adanya kepercayaan bahwa tradisi ini sudah dilaksanakan turun temurun dan sudah menjadi kewajiban setiap tahun yang harus dilaksanakan. Seperti yang disampaikan oleh Sulangkir (43),

“...Karena Tradisi Dawuhan ini sudah dipercaya masyarakat sebab selalu dilaksanakan sejak nenek moyang hingga sekarang."

(Sumber: Sulangkir (43), 14 Desember 2020)

Tradisi ini masih dilaksanakan karena tradisi tersebut dipercaya oleh masyarakat Desa Ngiliran bisa menjaga sumber air yang ada di Sumber Molang hal ini dinyatakan oleh Tabri (52). Menurut Endro (30), tradisi ini masih dilaksanakan karena ingin melestarikan adat yang ada di Desa Ngiliran karena sebagian masyarakat masih kental dengan adat termasuk Tradisi Dawuhan. Dalam setiap tradisi pasti memiliki tujuan tersendiri. Seperti halnya Tradisi Dawuhan yang memiliki tujuan agar sumber mata air Molang yang menjadi sumber kehidupan tidak kering. Seperti yang disampaikan oleh Purnomo (37), beliau menyatakan bahwa:

“...tujuan dilaksanakannya Tradisi Dawuhan adalah permohonan doa mengenai sumber molang dan juga sebagai wujud rasa syukur kepada tuhan karena sumber air dari Sumber Molang dapat menghidupi masyarakat tidak hanya Desa Ngiliran melainkan juga desa tetangga yang digunakan sebagai pengairan sawah."

(Sumber: Purnomo (37), 14 Desember 2020) 
Tujuan Tradisi Dawuhan ini bukan hanya mengharapkan air bersih, namun sumber air bersih yang membawa keberkahan dan kesejahteraan bagi masyarakat Desa Ngiliran dan desadesa sekitarnya.

\subsubsection{Prosesi Tradisi Dawuhan}

Berdasarkan hasil wawancara dari tetua adat, Sulangkir (43), beliau mengatakan bahwa prosesi dalam upacara Dawuhan terlebih dahulu mengadakan kesepakatan antara kepala desa beserta jajarannya, jajaran Forkopimca, dan perwakilan tokoh masyarakat bahwa akan dilangsungkan Tradisi Dawuhan. Prosesi dimulai dari bersih-bersih desa yang dilakukan oleh seluruh warga masyarakat Desa Ngiliran. Setelah lingkungan selesai dibersihkan batulah masyarakat membersihkan area Sumber Molang, tempat dimana dilaksanakan Tradisi Dawuhan. Setelah itu para pamong desa beserta istri datang membawa perlengkapan yang digunakan untuk ritual. Dilanjutkan dengan upacara adat, prosesi utamanya adalah membakar menyan dan dilanjutkan dengan doa bersama. Setelah selesai doa bersama yang dipimpin oleh tetua adat, selanjutnya ibu-ibu pamong menabur beras, uang koin, dan bunga wangi kedalam Sumber Molang yang diikuti oleh seluruh masyarakat Desa Ngiliran. Setelah itu dilanjutkan dengan slametan seluruh warga dan pemerintah desa yang ikut berpartisipasi. Dilanjutkan dengan membagikan makanan yang sudah disiapkan oleh setiap pamong kepada seluruh masyarakat. Kemudian tetuan adat mengunjungi kepala desa dan menyampaikan kepada sesepuh bahwa prosesi sudah dilaksanakan. Pada malam harinya diadakan pagelaran wayang kulit semalam suntuk.

\subsubsection{Ketentuan Tradisi Dawuhan}

Tradisi Dawuhan memiliki ketentuan yang harus diperhatikan di setiap prosesi pelaksanaannya. Tradisi ini dilakukan pada bulan Desember, Selasa Kliwon yang biasanya dilakukan setahun sekali. Seperti yang disampaikan oleh Endro (30) bahwa,

“..Tradisi Dawuhan ini hanya dilaksanakan setahun sekali, yakni di bulan Desember, tepatnya Selasa Kliwon. Dan tidak boleh dilaksanakan selain di hari dan bulan tersebut"

(Sumber: Endro (30), 14 Desember 2020)

Ketentuan khusus dalam pelaksanaan Tradisi Dawuhan ini tidak dilaksanakan di sembarang waktu, karena bisa menimbulkan kejadian yang tidak diinginkan oleh seluruh warga masyarakat Desa Ngiliran. Menurut Sulangkir (43), mengatakan bahwa,

“...Dahulu Tradisi Dawuhan pernah sekali dilakukan pada tanggal 17 Agustus sekaligus dilaksanakannya HUT-RI, namun dampaknya pertanian yang dialiri sumber air Molang tidak ada yang berhasil."

(Sumber: Sulangkir (43), 14 Desember 2020)

\subsubsection{Cara Melestarikan Tradisi Dawuhan}

Semua tradisi sudah selayaknya dilestarikan terutama oleh generasi mudah. Meskipun sekarang sudah zaman milenial, namun tradisi harus tetap berjalan dari generasi ke generasi. Endro (30) mengatakan bahwa meskipun zaman sudah berkembang, namun tradisi jangan sampai luntur. Dengan cara melibatkan generasi muda berpartisipasi di setiap upacara- 
upacara adat khususnya Tradisi Dawuhan. Generasi muda dan para tetua adat harus berperan aktif dalam melakukan upacara tradisi, seperti yang disampaikan oleh Sulangkir (43) bahwa:

“...Tradisi sudah seharusnya dilestarikan karena sudah menjadi adat sejak nenek moyang. Dilestarikan dengan cara para tetua adat aktif melakukan sosialisasi dengan anak muda. Sedangkan anak muda harus berperan aktif dalam prosesi tradisi"

(Sumber: Sulangkir (43), 14 Desember 2020)

Sedangkan menurut Purnomo (37), tidak hanya generasi muda yang harus berperan dalam pelestarian tradisi, namun tetua adat juga harus aktif dekat dengan generasi muda,

“...Tidak hanya generasi muda, tetua adat juga harus melakukan komunikasi dengan generasi muda. Supaya generasi muda dengan terbuka melestarikan tradisi"

(Sumber: Purnomo (37), 14 Desember 2020)

Generasi muda agar dapat melestarikan tradisi adalah dengan memberikan penjelasan kepada generasi muda supaya terus mengingat leluhur, karena meskipun zaman sudah berubah kita tidak bisa lepas dengan yang namanya tradisi nenek moyang, hal ini sesuai dengan yang disampaikan Tabri (52).

\subsection{Temuan Penelitian}

Berdasarkan hasil yang dilakukan dari wawancara bersama informan, maka diperoleh hasil paparan penelitian temuan penelitian di lapangan, yaitu:

\subsubsection{Tujuan Pelaksanaan Tradisi Dawuhan}

Tradisi Dawuhan merupakan tradisi yang dilaksanakan secara turun temurun dan sudah menjadi kebiasaan masyarakat. Dalam tradisi isi menggunakan sesajen kemenyan yang dibakar. Tujuan pelaksanaan Tradisi Dawuhan adalah wujud rasa syukur dan permohonan doa mengenai sumber mata air Molang.

\subsubsection{Makna Simbolik Perlengkapan Tradisi Dawuhan}

Dalam tradisi ini menggunakan beberapa perlengkapan untuk prosesi tradisi yaitu (1) Jadah, jenang, ketupat, labu bermakna sebagai hasil panen dari hasil pengairan sumber air Molang. (2) Ngantenan, yang dibuat dari ketan yang dibentuk seperti sepasang tubuh manusia yang memiliki makna sebagai nenek moyang. (3) Punar, pisang sepasang, dan takir bermakna sebagai sesuatu yang mengantarkan atau mengiringi nenek moyang hingga saat ini. (4) Ontong pisang bermakna sebagai sesuatu yang menggambarkan kejadian terbentuknya sumber air Molang. (5) Tebu hitam bermakna sebagai seorang manusia harus memiliki hati yang teguh kepada Tuhan Yang Maha Esa. (6) Kelapa hijau bermakna supaya air sumber Molang dapat menghidupi banyak masyarakat dan bermanfaat serta tidak pernah surut.

\subsubsection{Ketentuan Khusus Tradisi Dawuhan}

Tradisi Dawuhan di Dusun Ngiliran Kecamatan Panekan sudah ada sejak zaman nenek moyang dan dilaksanakan turun temurun hingga sekarang. Dalam tradisi ini, terdapat ketentuan khusus yakni dilakukan pada bulan Desember, Selasa Kliwon yang biasanya dilakukan setahun sekali. Dalam pelaksanaan Tradisi Dawuhan ini tidak dilaksanakan di 
sembarang waktu, karena bisa menimbulkan kejadian yang tidak diinginkan oleh seluruh warga masyarakat Desa Ngiliran Kecamatan Panekan Kabupaten Magetan.

\subsubsection{Upaya Pelestarian Tradisi Dawuhan}

Upaya yang dilakukan untuk melestarikan Tradisi Dawuhan khususnya generasi muda yakni dengan cara mengadakan sosialisasi, memperkenalkan dan memberikan pemahaman mengenai Tradisi Dawuhan tujuannya supaya generasi muda mengingat tradisi yang sudah dibangun nenek moyang. Selain itu, para tokoh masyarakat harus mendekatkan diri kepada generasi muda dan mengharuskan generasi muda ikut aktif berpartisipasi dalam pelaksanaan tradisi.

\subsection{Pembahasan}

Tradisi Dawuhan sejatinya telah menjadi bagian yang tidak terpisahkan dari masyarakat Ngiliran khususnya warga Desa Ngiliran Kecamatan Panekan Kabupaten Magetan. Berdasarkan temuan penelitian yang meliputi tujuan pelaksanaan Tradisi Dawuhan, makna simbolik perlengkapan Tradisi Dawuhan dan prosesi serta ketentuan khusus Tradisi Dawuhan.

\subsubsection{Tujuan Dilaksanakan Tradisi Dawuhan}

Pertama, Tradisi Dawuhan sebagai tradisi dan ritual yang memiliki tujuan wujud rasa syukur dan nguri-uri budaya yang mana tradisi ini tetap dilaksanakan dengan alasan bahwa tradisi ini telah membudaya dari dilaksanakan nenek moyang dari masa ke masa dan tetap dilaksanakan hingga saat ini oleh warga masyarakat Desa Ngiliran (Lamazi, 2005). Warga masyarakat percaya dengan menghormati tradisi yang sudah menjadi kebiasaan.

Kedua, tujuan dilaksanakannya Tradisi Dawuhan ini berkaitan dengan teori interaksionisme simbolik yaitu terdapat dalam konsep mind (pemikiran), warga masyarakat Desa Ngiliran memiliki pemikiran yang dituangkan dalam bentuk tradisi atau ritual yang tak lain memiliki tujuan sebagai perwujudan rasa syukur kepada Tuhan Yang Maha Esa. Yang selanjutnya adalah konsep self (diri) dikarenakan tujuan dari Tradisi Dawuhan ini adalah bersyukur kepada Yang Maha Kuasa, yang mana bentuk interaksi yang dilakukan masyarakat dengan sang pencipta, maka warga masyarakat desa berinteraksi melalui ritual-ritual yang ditujukan sebagai sarana berkomunikasi. Dan terakhir adalah konsep society (masyarakat) antara masyarakat satu dengan masyarakat yang lain saling berinteraksi dan saling terlibat dengan tujuan yang sama terkait tujuan dilaksanakannya Tradisi Dawuhan.

\subsubsection{Makna Simbolik yang Terkandung dalam Tradisi Dawuhan}

Pertama, makna simbolik yang terdapat pada pelaksanaan Tradisi Dawuhan diartikan sebagai sarana komunikasi antara suatu yang digunakan dengan suatu yang lainnya. Sesuatu yang digunakan berarti perlengkapan yang digunakan yang didalamnya telah mengandung arti.

Kedua, Makna simbolik ini berkaitan dengan teori interaksionisme simbolik terdapat tiga konsep, yaitu (1) Mind (pemikiran) pemikiran yang bertujuan sebagai sarana komunikasi yang dilakukan kepada Sang Maha Kuasa, karena komunikasi yang dilakukan ini menggunakan perlengkapan yang bermakna simbolik seperti kelapa hijau yang diibaratkan sebagai sumber 
mata air. (2) Self (diri) masyarakat dapat mengaplikasikan makna simbolik yang terkandung dalam Tradisi Dawuhan dan masyarakat dapat mempercayai terkait makna simbolik yang terkandung dalam Tradisi Dawuhan. (3) Society (masyarakat) masyarakat bersama-sama membentuk suatu konstruksi untuk membangun suatu makna simbolik melalui benda- benda yang ada disekitar mereka yang dapat digunakan sebagai sarana dalam ritual.

\subsubsection{Ketentuan Tradisi Dawuhan}

Pertama, Seperti yang diungkapkan oleh (Lamazi, 2005) tradisi berasal dari kata traditium yang berarti segala sesuatu yang telah ditransmisikan dan diwariskan secara turun temurun. Hal ini seperti Tradisi Dawuhan yang sudah ada sejak zaman dahulu yang dilaksanakan turun temurun hingga saat ini yang memiliki prosesi dan ketentuan yang berlaku.

Kedua, hal ini juga berkaitan dengan teori interaksi simbolik yaitu dalam konsep mind (pikiran), sebagian masyarakat awam mengalami perbedaan pemahaman dengan tetua adat mengenai Tradisi Dawuhan. Kemudian konsep self (diri), masyarakat awam mengalami kendala saat memahami prosesi dalam tradisi tersebut. Kemudian masyarakat awam memilih mengikuti setiap prosesi dalam tradisi tersebut hingga menemukan makna sesungguhnya. Kemudian society (masyarakat), masyarakat akan membentuk pikiran dan diri masyarakat. Ketika tetua adat melakukan setiap prosesi, masyarakat akan cenderung menyesuaikan diri dengan apa yang dilakukan oleh tetua adat. Dengan demikian, kendala dalam masyarakat awam akan hilang karena masyarakat awam mampu menyesuaikan diri.

\subsubsection{Upaya Pelestarian Tradisi Dawuhan}

Pertama, setiap tradisi sudah seharusnya dilestarikan oleh para generasi muda. Secara garis besar, tradisi merupakan warisan budaya dan kebiasaan orang-orang terdahulu yang masih tetap dilestarikan secara terus menerus hingga sekarang. Tradisi ritual adalah kegiatan yang diberikan atau diteruskan dari masa lalu ke masa kini (Sedyawati, 1991).

Kedua, hal ini juga berkaitan dengan konsep interaksi simbolik, yaitu dalam konsep mind (pikiran) dimana generasi muda harus memiliki pikiran untuk meneruskan tradisi dengan berinteraksi dengan tokoh adat. Selain itu tokoh adat juga memperkenalkan dan memberikan arahan, penjelasan, dan pemahaman mengenai Tradisi Dawuhan. Kemudian self (diri) berarti generasi muda harus mempunyai kesadaran diri untuk melestarikan sebab merekalah yang akan meneruskan tradisi yang sudah ada sejak nenek moyang hingga sekarang. Kemudian society (masyarakat) yakni generasi muda sebaiknya dilibatkan dalam pelaksanaan tradisi sehingga nantinya merekalah yang berperan menjadi tokoh masyarakat untuk meneruskan tradisi yang sudah berjalan hingga saat ini.

\section{Simpulan}

Berdasarkan hasil penelitian yang dilakukan mengenai makna simbolik Tradisi Dawuhan dapat peneliti simpulkan antara lain: (1) Tradisi Dawuhan adalah tradisi yang bertujuan sebagai wujud rasa syukur dan permohonan doa mengenai sumber mata air Molang yang sudah dilakukan nenek moyang dan sudah menjadi kebiasaan masyarakat hingga sekarang. (2) Prosesi dalam upacara Dawuhan terlebih dahulu mengadakan kesepakatan antara kepala desa beserta jajarannya, jajaran Forkopimca, dan perwakilan tokoh masyarakat bahwa akan dilangsungkan Tradisi Dawuhan. Prosesi dimulai dari bersih-bersih desa yang dilakukan oleh seluruh warga masyarakat Desa Ngiliran. Setelah lingkungan selesai 
dibersihkan batulah masyarakat membersihkan area Sumber Molang, tempat dimana dilaksanakan Tradisi Dawuhan. Setelah itu para pamong desa beserta istri datang membawa perlengkapan yang digunakan untuk ritual. Dilanjutkan dengan upacara adat, prosesi utamanya adalah membakar menyan dan dilanjutkan dengan doa bersama. Setelah selesai doa bersama yang dipimpin oleh tetua adat, selanjutnya ibu-ibu pamong menabur beras, uang koin, dan bunga wangi kedalam Sumber Molang yang diikuti oleh seluruh masyarakat Desa Ngiliran. Setelah itu dilanjutkan dengan slametan seluruh warga dan pemerintah desa yang ikut berpartisipasi. Dilanjutkan dengan membagikan makanan yang sudah disiapkan oleh setiap pamong kepada seluruh masyarakat. kemudian tetuan adat mengunjungi kepala desa dan menyampaikan kepada sesepuh bahwa prosesi sudah dilaksanakan. Pada malam harinya diadakan pagelaran wayang kulit semalam suntuk. (3) Makna simbolik yang terkandung dalam Tradisi Dawuhan yaitu sebagai sarana komunikasi yang menggunakan perlengkapan tradisi yang memiliki makna simbolik sebagai penyampaian tujuan kepada Tuhan Yang Maha Esa. (4) Upaya untuk mendorong generasi muda untuk melestarikan Tradisi Dawuhan yakni dengan memperkenalkan dan memberikan arahan, penjelasan, dan pemahaman mengenai Tradisi Dawuhan dengan tujuan agar para generasi muda selalu mengingat nenek moyang.

\section{Daftar Rujukan}

Ardianto, E., \& Q-Anees, B. (2011). Filsafat Ilmu Komunikasi. Bandung: Simbiosa Rekatama Media.

Effendy, O. U. (1989). Kamus Komunikasi. Bandung: Mandar Maju.

Khamidah, K. (2019). Nilai-Nilai Pendidikan Islam Dalam Tradisi Bersih Desa di Purbosari Kecamatan Seluma Barat Kabupaten Seluma (Doctoral dissertation, IAIN BENGKULU).

Kirk, J., Miller, M. L., \& Miller, M. L. (1986). Reliability and validity in qualitative research (Vol. 1). Beverly Hills, CA: Sage Production.

Koentjaraningrat, R. M. (2015). Pengantar Ilmu Antropologi. Rineka Cipta

Lamazi, L. (2005). Tradisi Tambe Kampung Dalam Masyarakat Islam di Desa Tempapun Kuala Kecamatan Gading Kabupaten Sambas (Skripsi, Jurusan Dakwah STAIN Pontianak).

Miles, M. B., \& Huberman, A. M. (1992). Qualitative data analysis. Sage.

Neuman, W. L. (2000). Social Research Method: Qualitative and Quantitative Approaches, 4th Edition. Boston: Allyn \& Bacon.

Ningrum, S. U., \& Muthali'in, A. (2018). Implementasi Nilai Persatuan dalam Pancasila pada Tradisi Bersih Desa (Punden) Studi Kasus di Desa Tambakboyo Kabupaten Sukoharjo Kecamatan Tawangsari (Doctoral dissertation, Universitas Muhammadiyah Surakarta).

Rizkiawan, I. (2017). Faktor-faktor yang mempengaruhi persepsi masyarakat tentang makna sesajen pada upacara bersih desa. Jurnal Tata Boga, 6(2).

Sedyawati, E. (ed.), (1991). Seni dalam Masyarakat Indonesia. Jakarta: PT. Gramedia. 